УдК 621.391

\title{
КВАЗИПРАВДОПОДОБНАЯ ОЦЕНКА ВРЕМЕННЫХ ПАРАМЕТРОВ ПОСЛЕДОВАТЕЛЬНОСТИ СВЕРХШИРОКОПОЛОСНЫХ СИГНАЛОВ НЕИЗВЕСТНОЙ ФОРМЫ ПРИ ВОЗДЕЙСТВИИ УЗКОПОЛОСНЫХ ПОМЕХ
}

\author{
ТРИФОНОВ А.П. ${ }^{1}$, БЕСПАЛОВА М.Б. ${ }^{1}$, ТРИФОНОВ П.А. ${ }^{2}$, ГУЩИН И. В. ${ }^{2}$ \\ ${ }^{1}$ Воронежский государственный университет, \\ Россия, Воронеж, 394006, Университетская пл., д. 1 \\ ${ }^{2}$ Военный учебно-научный иентр военно-воздушных сил \\ «Военно-воздушная академия им. проф. Н.Е. Жуковского и Ю.А. Гагарина», \\ Россия, Воронеж, 394064, ул. Старых Большевиков, 54A
}

\begin{abstract}
Аннотация. Исследованы характеристики квазиправдоподобной оценки времени прихода и периода повторения сверхширокополосного сигнала неизвестной формы, принимаемого на фоне узкополосных помех с неизвестными параметрами и гауссовского белого шума
\end{abstract}

Ключевые слова: сверхширокополосная оценка; узкополосная помеха; характеристики оценок

На сегодняшний день использование сверхширокополосных сигналов (СШПС) является передовой и одной из наиболее перспективных технологий [1-6], которая находит широкое применение в самых различных радиоэлектронных системах, включая системы военного назначения.

Физическая основа целесообразности использования сверхширокополосных сигналов очевидна - количество информации, передаваемой в единицу времени, прямо пропорционально полосе используемых частот. Альтернативой этому является увеличение времени передачи информации, но в радиолокации время контакта с целью всегда ограничено, поэтому проблема повышения информативности при использовании традиционных подходов остается.
Во многих прикладных задачах радиолокации приемник РЛС должен измерять основные временные параметры отраженной от цели последовательности СШПС - время прихода и период следования. В [6] рассмотрена оценка максимального правдоподобия этих параметров при воздействии только гауссовского белого шума (ГБШ). В [3] исследованы алгоритмы оценки времени прихода и периода повторения последовательности СШПС на фоне помех, в качестве модели которых использовался гауссовский узкополосный процесс (ГУП) [7]. При этом форма СШПС считалась априори известной.

В реальных условиях, форма принимаемого сигнала неизвестна, т.к. изменяется при отражении от объекта (радиолокация), при распространении в различных средах (навигация,

* Работа выполнена за счет гранта Российского научного фонда (проект №15-11-10022). 